\title{
The Fort of Bernia by Giovanni Battista Antonelli
}

\author{
Sandro Parrinello - Silvia Bertacchi
}

Published online: 22 November 2014

(C) Kim Williams Books, Turin 2014

\begin{abstract}
This paper deals with the relationship between geometrical rules and proportions as design techniques for military architecture proposed by the engineer Giovanni Battista Antonelli during the late sixteenth century. After a short introduction about the Antonelli family of engineers, the paper focuses on a case study, the Fort of Bernia near Alicante (Spain). The study of the original drawings and reports on the building preserved in the Spanish national archives has been a fundamental means of gathering details about the defensive structure. Additionally, a three-dimensional survey carried out on what remains of the outpost allowed a careful analysis reconstruction of its history and the geometrical proportion of its parts. In conclusion this project, a perfect example of geometrical design for a defensive purpose, represents Antonelli's total failure as a military engineer, because his too strict adoption of the theoretical model in a mountainous site contradicted all the considerations made in his treatise on modern fortification.
\end{abstract}

Keywords Fortifications, military architecture, Spain ·

Sixteenth century · Giovanni Battista Antonelli · Fort of Bernia ·

Representations of architecture, archive documentation .

Geometric analysis $\cdot$ Perspective $\cdot$ Proportional analysis

\footnotetext{
S. Parrinello

Dipartimento di Ingegneria Civile e Architettura, Università di Pavia, Via Ferrata 1, 27100 Pavia, Italia

e-mail: sandro.parrinello@unipv.it

S. Bertacchi $(\bowtie)$

Scuola di Ingegneria e Architettura, Alma Mater Studiorum Università di Bologna, Viale del

Risorgimento 2, 40136 Bologna, Italia

e-mail: silvia.bertacchi@unibo.it
} 


\title{
The Fort of Bernia by Giovanni Battista Antonelli
}

\author{
The Antonelli Family and Research Done to Date
}

In the overview of the sixteenth- and seventeenth-century defensive architecture, the Antonellis, Italian engineers natives of Gatteo in Romagna, actively contributed to the development of military architecture. ${ }^{1}$ The reputation of this family depends on the remarkable competence of its members, who dealt with the defence of one of the most important European powers of the period, the Spain of Charles V (1500-1558), Philip II (1527-1598) and Philip III (1578-1621), in whose service they worked for almost a century, both for military planning and hydraulic engineering.

Nowadays the defensive buildings designed by the Antonellis, almost all of which have been declared World Heritage Sites by UNESCO, still show the transmission of cultural systems and military technology through the strongholds designed by Giovanni Battista Antonelli (1527-1588), his brother Battista (1547-1616) and his son Juan Bautista (1585-1649), and numerous nephews, including Cristoforo Roda Antonelli, Cristoforo and Francesco Garavelli Antonelli. ${ }^{2}$ Thanks to all these engineers the concepts of modern military architecture created in Italy were spread throughout Europe and to the New World.

Original research dealing with some of the well-known fortifications designed by the Antonellis, in particular in the Caribbean area, has been carried out by Sandro

\footnotetext{
1 An important nineteenth-century historian wrote this positive comment on the Antonellis: La familia de los Antonelli dio a España excelentes arquitectos militares e hidráulicos, contando con Roda y los Garavelli. Todos salieron de la misma estirpe, que produjo la Romaña en Italia, y al que debemos las mejores fortificaciones de la península, las que tuvimos en áfrica y las que aún subsisten en América, porque son dignos de los mayores elogios y de los lugares que ocupan en esta historia (Llaguno y Amirola 1829: vol. 4, p. 13). For information on the whole family see also Maggiorotti 1939: vol. III, 131 et seq.); Sartor 2004b; Gasparini 2007.

${ }^{2}$ Battista Antonelli (1547-1616) was the younger brother of Giovanni Battista, and he was born in Gatteo too. In his early years he moved to Spain to work in the fortification of the kingdom by request of his elder brother, completing his education in the military engineering with Vespasiano Gonzaga. He worked in Cartagena (1575), Alicante (1575) and Peñíscola (1579). He became the most famous of the family because he moved to America in order to complete the defensive system of the New World. He was in charge of reconnaissance missions in Cartagena des Indias, Panamá, Chagres, Portobello, La Habana in 1586. After, he projected fortresses to protect the coasts from pirate attacks, including those in Santo Domingo, Puerto Rico, Florida and Mexico.

Cristoforo Roda Antonelli (1561-1631) was the nephew of Giovanni Battista and Battista, son of their sister Rita. He was born in Italy too and moved to Spain in 1578 to work in hydraulic engineering and river navigation with his eldest uncle. Starting from 1591, Cristoforo moved to America to help his uncle Battista in the fortresses of La Habana, then Cartagena of the Indies (Colombia), where in 1614 he was in charge of the construction of the San Felipe bastion. After 1622 he projected the fort to protect the salt pan of Araya, and after 1626 he designed the Castle of San Lorenzo del Chagres.

Juan Bautista Antonelli (1585-1649) was the only child of Battista Antonelli, and he was born in Spain. He worked with his father in the Caribbean area, and with his cousin Cristoforo Roda in the salt pan of Araya, and then in Puerto Rico and Cartagena of the Indies.

Cristoforo (1550-1608) e Francesco Garavelli Antonelli (1557-1593), the other nephews of Giovanni Battista and sons of his sister Catalina, were both born in Italy. They moved to Spain around 1570 and worked with their uncles as military engineers. In particular, Cristoforo worked in Africa and Tortosa, and was the manager for the construction of the dyke of Tibi in 1587-88 (Gasparini 2007).
} 
Parrinello since 2005. The first collaboration with the Cuban institutions was focussed on studying and surveying the Fort San Pedro de la Roca in Santiago de Cuba. This research project, aimed at analysing the whole defence complex of Santiago de Cuba, was part of an agreement between Italian researchers and University, local historians and superintendence and the managing authorities in charge of the preservation and maintenance of the stronghold. These studies also had the objective of promoting the idea of a global museum, virtual if not physical, to disseminate all over the world the knowledge about these important engineers and their works, that can be considered a cultural link between the Italian Renaissance tradition and the overseas territories of Central America. These works have never been studied before in the light of the connection between military culture and territory or defensive architecture and geometrical design, analysed thanks to accurate digital surveys that represents reality in a reliable way. Moreover by means of these devices, a great number of data can be gathered, creating a complete database and cataloguing of all the drawings of the forts and the information about their state of preservation, that can become an opportunity to enhance sixteenth century military architecture and even develop local economy.

Other collaborations concerned the survey of the Morro in Havana in 2008, the fort of San Juan in Puerto Rico (2009), where the project was supported by the National Service Park and by a special partnership with the University of Porto Rico, and also the documentation of the bay of Portobelo in Panama (2010), begun in December 2010 in collaboration with the Protectorate of Portobelo and San Lorenzo in the province of Colón. Moreover the fortress of San Juan de Ulúa in Mexico (2012) and Fort San Lorenzo in Panama (2013). In respect to the European fortresses, we can include also the 3D scanner laser survey campaign of the Fort of Bernia in Spain and of the city walls of Peñíscola, both attributed to the Antonelli brothers (2011).

Within this framework, several survey campaigns have been carried out during the years, involving students, researchers and Ph.D. students from the University of Florence, all with the purpose of examining in depth the works by the Antonelli family.

These activities have resulted in numerous congresses (Parrinello-Bertacchi 2012; Parrinello-Bertacchi 2013) and workshops organized in various countries, and a number of degree theses and Ph.D. theses over the years (Bertacchi 2013a), various public exhibitions of the graphic material such as plans, front views and cross-sections of the fortresses, and high-resolution 3D models of the existing architecture, not always open to visitors, for virtual exploration through interactive platforms. ${ }^{3}$

\section{Giovanni Battista Antonelli, Military Engineer}

Among the members of the Antonellis who contributed to the defence of the Spanish Crown, Giovanni Battista the eldest was the first promoter of the activity of the family in the Iberian Peninsula, and the leader of the generation of technicians.

\footnotetext{
3 The list of exhibitions that have resulted from this research can be consulted in the complete catalogue of documented fortresses (Parrinello 2012).
} 
He was born in Italy in 1527, the first of the five sons of Gerolamo Antonelli and Lucrezia Saure. Despite a lack of information about his initial years, scholars (Cámara Muñoz 2004: 163; Sartor 2004a: 16) have assumed that he was educated to become a professional soldier, but also with an education grounded in military theory.

During the conflict between Florence and Siena in 1554, he participated in the battle on the side of the Florentines, supported by the Spanish army. In that occasion he probably met some of the most important engineers of the period, such as Pietro Cataneo and Giovanni Battista Zanchi, experts in the art of fortification and both authors of treatises on modern defences published in that very year. ${ }^{4}$

Following his mentor, Count Gianfrancesco dei Conti Guidi da Bagno, marquis of Montebello and Lord of the city of Gatteo, he moved to Spain, probably in 1559, after the treaty of peace of Cateau-Cambrésis between Spain and France.

While he was in Toledo and in a moment of peace and quiet, Antonelli wrote his treatise on modern fortifications, entitled Epitomi delle fortificationi moderne di Giovambatta Antonelli (Antonelli 1560). The three books that compose the Epitomi were never published, but luckily a manuscript copy has survived arrived to the present day and is now preserved in the Museo del Ejército (Army Museum) in Toledo.

Antonelli wrote this treatise to prove to the foreign king and to his councils that he was an experienced engineer; the book thus served as his personal "business card". Thanks to his contacts with the general captain of artillery Juan Manrique de Lara, Antonelli entered the ranks of the Spanish military. His career took a leap forward and he became one of the King's closest and most trustworthy engineers.

For 20 years Antonelli dealt with military engineering, including several reconnaissance missions to the coastal area followed by detailed reports on the situation, numerous projects of towers, strongholds and citadels to protect the coastal settlements from pirate attacks (Fig. 1). ${ }^{5}$

An excellent strategist, he demonstrated his skills in the modern fortification of the Italian School, but filtering them through his personal experience and a consideration of the geographical features of the Iberian Peninsula and local traditional building techniques. He arrived at personal solutions in the military field, suggesting a different use of common materials, such as the technique of rammed earth as protection against the cannon fire, and disseminated an innovative concept

\footnotetext{
${ }^{4}$ In the second half of the sixteenth century the majority of treatise writers considered geometry as the tool to design fortresses. These two authors contributed to the definition of the military knowledge and their works were very famous at the time (Cataneo 1554; Zanchi 1554). According to the scholars (Sartor 2004a, p.13; Gasparini 2007, p. 31) Antonelli met them during the battle and probably he learned about their concepts about the defensive topic.

5 Apart from the Fort of Bernia, Antonelli planned the city walls for Alicante, the new bastions for the castle of Santa Barbara of the same city, the citadel of Pamplona, none of which was ever realized. On the contrary, it seems that the city walls of Cartagena were constructed, but soon after destroyed because of their inefficiency, as well as the towers projected for the Murcia coasts, made of rammed earth and shortly destroyed. Other projects by the engineer underwent changes, even radical ones, on the part of Vespasiano Gonzaga, as in the case of the fortress in Mazalquivir, Algeria, where Antonelli's plan was distorted.
} 


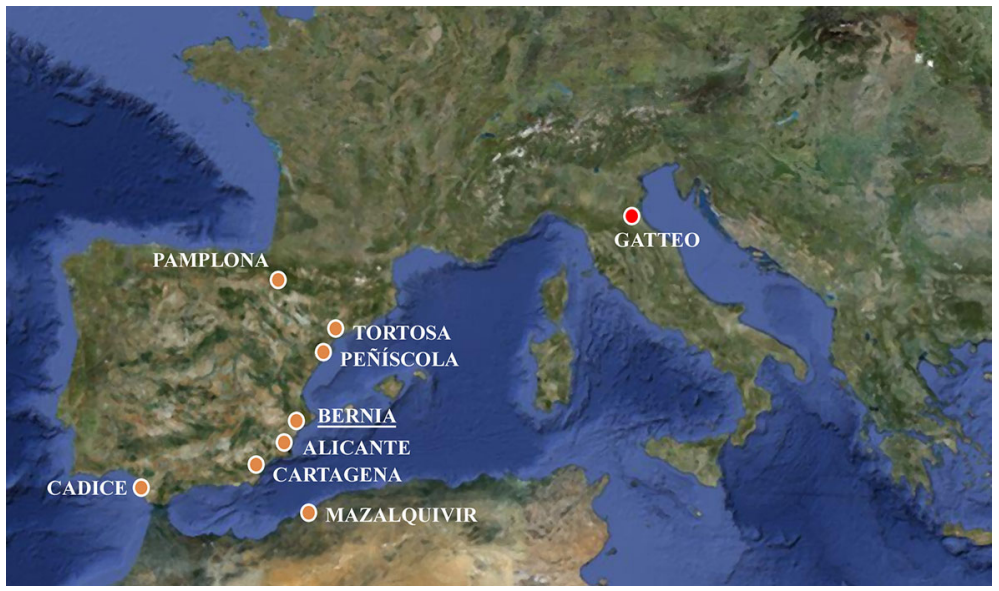

Fig. 1 Some of the Spanish and North African localities where Antonelli worked in the period 1559-1580. Elaboration based on a satellite image by Google Maps 2013

of defence, based on the idea that the country could be considered as an overall territory to protect as if it were a huge city.

In spite of his commitment, the results of his work were not always positive, and the failure of most of his projects was due to the insufficient versatility of his "universal model", created by means of geometrical rules and not easily adaptable to any site, as the case study presented here will show.

The archival documents consulted revealed his complex professional situation: he was constantly competing with other engineers, subject to criticism regarding his design and technical choices, too tied to the use of proportions and geometry. He was also described as bad-tempered, ambitious and envious of his colleagues, facts that to some extent led to his abandonment of the military field. In fact, from 1580 up to his death in 1588, in the light of the fact that the longest river of the peninsula was completely under the possession of Spain thanks to the annexation of Portugal, Antonelli devoted himself to fluvial navigation and is even today remembered as an excellent hydraulic engineer.

\section{The History of Fort of Bernia}

Starting from the second half of the sixteenth century, the Spanish Crown ordered its best engineers and technicians to fortify the whole kingdom. This was aimed at protecting both the coastal area, subject to frequent pirate attacks, and the inland, populated by a large number of Muslims. On the Eastern coast the king's plan was implemented through the construction of the Fort of Bernia, located on the promontory of the same name (Fig. 2), whose design is attributed to Giovanni Battista Antonelli.

The peculiar geographic structure of the mountainous area, in which hiking trails represented the only way to cross, had always given considerable strategic 


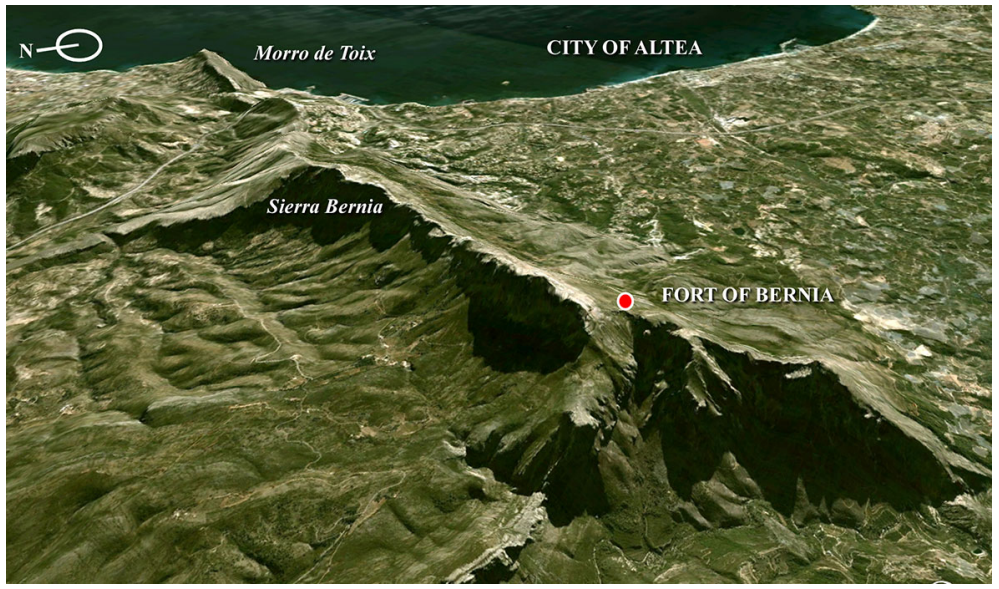

Fig. 2 Northern view of the Sierra Bernia (Alicante), district of Callosa d'En Sarrià. The fort (indicated by the red dot) is located on the southern slope of the mountain, around $800 \mathrm{~m}$ sea-level, where there is the only safe pass to climb the mountainous area. Elaboration based on a satellite image by Google Maps 2013

importance to the site. Some studies (Pastor Fluixá 1986; León Vidal 2009; Valor Serra 1950) document the existence of a tower dating back to the thirteenth century; this was in ruins in 1561 when Antonelli visited the area. The isolation of the place and the richness of spring waters, which allowed survival even on the top of the mountain, had turned the area into the den of all kinds of outlaws and, since the beginning of the sixteenth century, into the refuge of the Muslim population hiding from the authorities in order to escape the forced baptism.

In 1561 Antonelli was charged to visit and report the best solution for occupying the area. He began with the reconnaissance mission in the Sierra Bernia, at that time still populated by the Moorish people, of whom the king suspected of planning to revolt. The engineer received the instructions in a document, written in Italian, concerning a list of the information that was necessary for the organization of a military action. ${ }^{6}$ After several inspections, Antonelli completed three detailed reports, ${ }^{7}$ proposing the construction of a fort on the southern side of the mountain, in a steeply sloping site with a wide view of the coastal zone (Figs. 3, 4), that would

\footnotetext{
6 The original document (dated 2 October 1561) is conserved in the Archivo General de Simancas with the following shelf mark: AGS, Estado, 329-I, fol. 35: Los puntos de la istrució(n) q(ue) llevo Juan bap.ta antoneli Ingeniero q(ue) fue a Valen.a a 2 de otubre 1561. Another undated copy of the instructions, almost identical to the original but written in Spanish, is preserved among the manuscripts of the section of old collections in the Bibliothèque National de France in Paris, with the following shelf mark: BNF, Archives et manuscrits, Espagnol 161, Ancien fonds, n. 10244; Mazarin, Registre de copies de lettres et de documents diplomatiques émanés pour la plupart du duc d'Al..., fol. $156 \mathrm{r}-158 \mathrm{v}$, doc. 36, undated (probably 1561), entitled Instrucion á vos Juan Baptista Antonelli, ingeñero, para que vays a reconosçer el sitio de la sierra de Vernia.

7 The three documents have the following shelf marks: AGS, Estado, 329-I, (probably 1561-1562): fol. 36, Relatione della Montagna, ò, Serra di Spadan; fol. 37, Relatione della Montagna, ò, Serra di Bernia; fol. 38, Discorso sopra le due montagne di Spadán et di Bernia.
} 


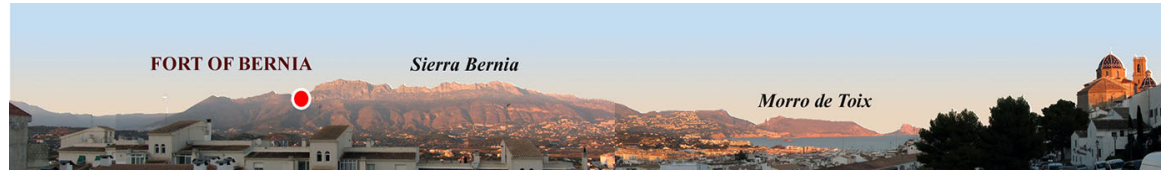

Fig. 3 Southern view of the Sierra Bernia taken by the near city of Altea. Photo by Silvia Bertacchi

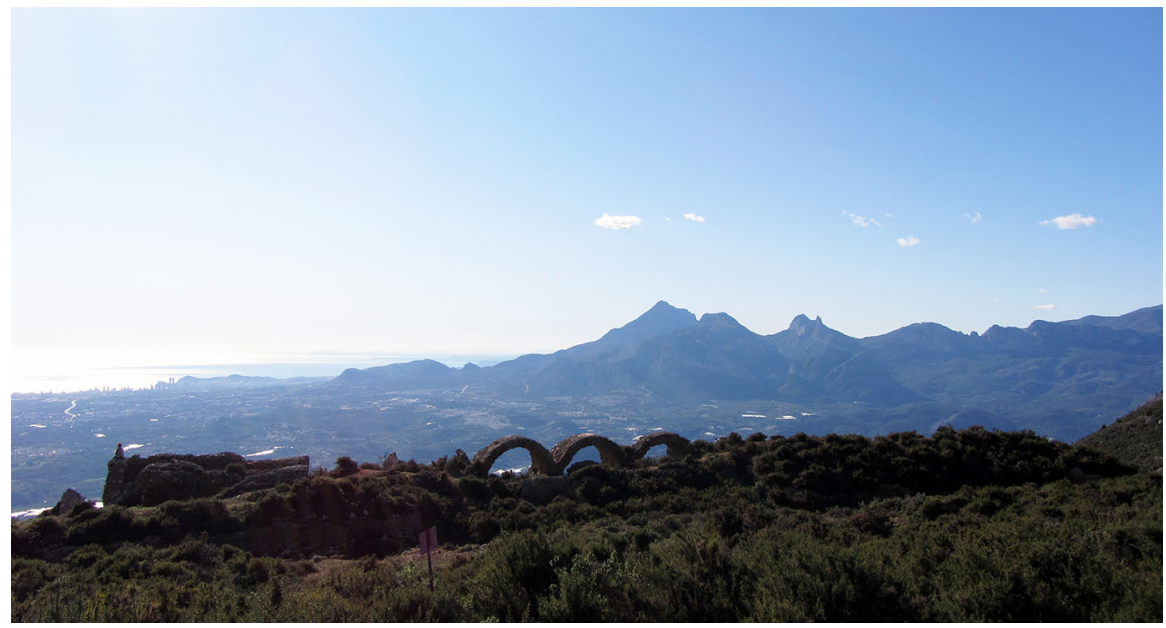

Fig. 4 Spectacular view of the coastline by the remains of the Fort of Bernia. Photo by Silvia Bertacchi

serve for surveillance of pirates' galleons, as well as control of the Muslims and the wellsprings (Figs. 5, 6).

The archival documents indicate that the construction of the fort began in midApril 1562 (Cebrián Gimeno 1997; Arciniega García 1999: 72), and that the work proceeded quickly because the Council had grounds to fear that the Moorish population was organizing an impending revolt. Construction work ended on 27 August; according to Jaume Pastor Fluixá (1986: 53) and Sebastiá Garcia Martínez (1980: 27) the fort must have been at an advanced stage by that point, because the king gave the engineer the order to Antonelli to leave the site and go back to visit the Spanish coasts. ${ }^{8}$

In the archives of Valencia are preserved numerous coeval documents on the fort, useful for studying the history of the building in detail. Thanks to the reports we know that internally the building was well-distributed (Figs. 7, 8).

The residential area was divided into common areas for the soldiers and larger rooms for the captain and the military chaplain. The service rooms included a kitchen with oven, storage for wine, oil and flour, as well as protected areas reserved

\footnotetext{
8 Alicia Cámara Muñoz states that the order to Antonelli to leave is in AGS, GA, leg. 70, fol. 220 (Cámara Muñoz 2005: 9). Regarding the end of construction, the local historian Gaspar Escolano postpones the end of the stronghold to 1570 (Escolano 1611: 1423).
} 


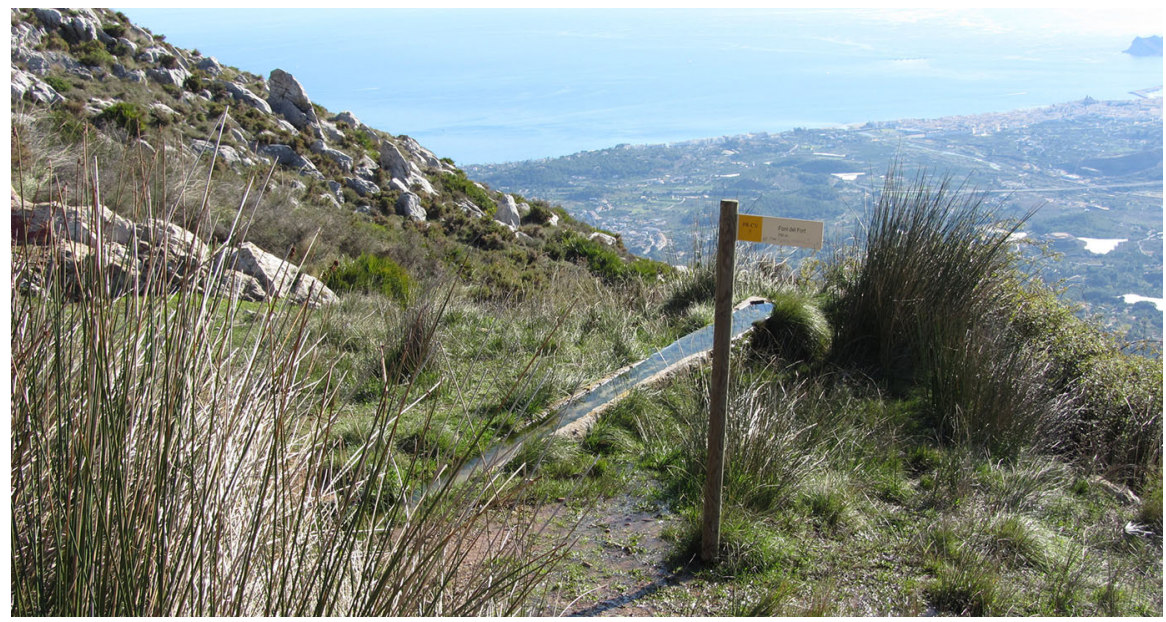

Fig. 5 The "Font del Fort", the spring near the fort that flows out of the mountain slope. Photo by Silvia Bertacchi

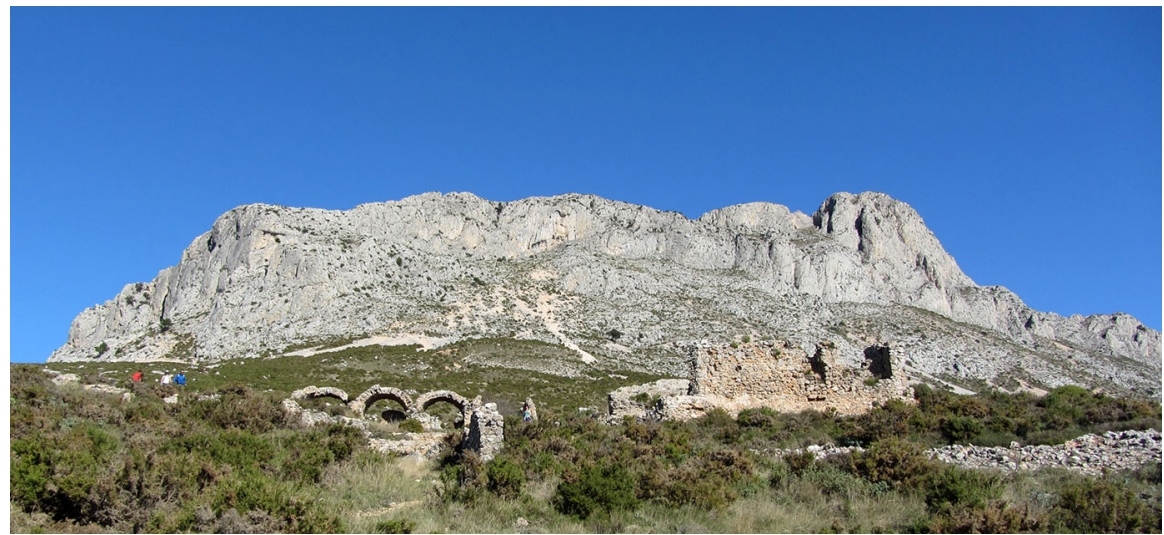

Fig. 6 The existing ruins of the Fort of Bernia. Photo by Silvia Bertacchi

to armaments, such as ammunition and gunpowder depots. There was a church whose location is not certain and at least two tanks to store rainwater.

In spite of the efficiency in plan, the total inefficacy of the fort from a military point of view was evident. The objectives for which it had been built were all unfulfilled, and the expensive maintenance costs of the guard and the building itself were not justifiable. First of all the stronghold was symmetrical and calculated to resist to firearms, even though an attack with heavy cannons on the top of a mountain was very unlikely, in part because of the difficulties of the mountain path, but especially because the Moorish people were not equipped with firearms. Moreover, despite the undeniable strategic importance of the site, the distance from the coast meant that the soldiers of the garrison hardly ever took an active part in military actions, apart from the sighting of enemy ships. Only on a few occasions 


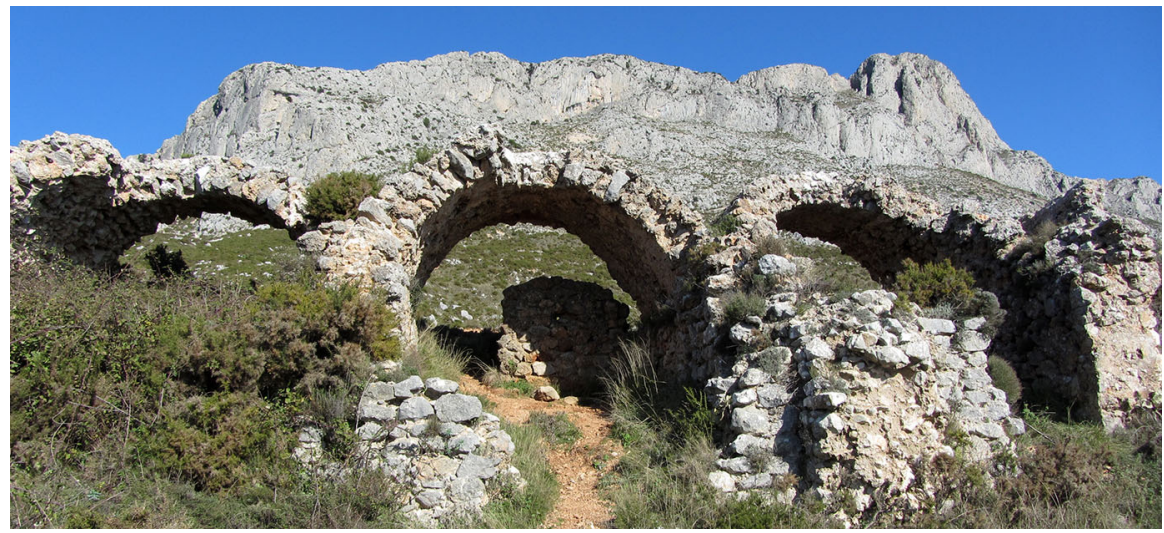

Fig. 7 Surviving vaults of the ancient quarters of the soldiers. Photo by Silvia Bertacchi

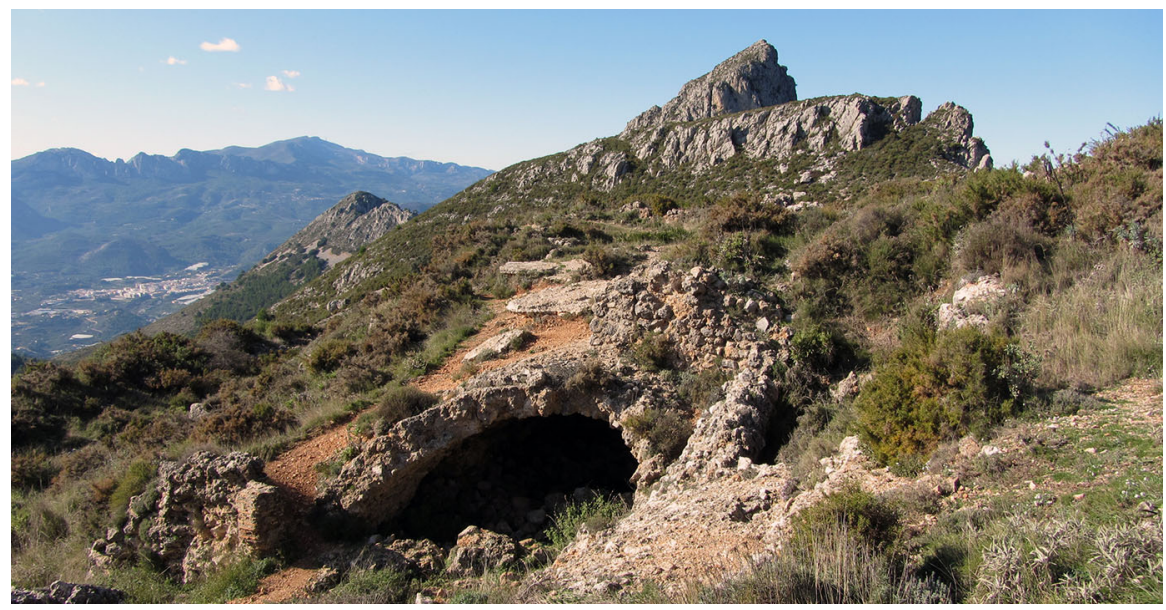

Fig. 8 The collapsed vault covering the dugout of the western bastion seen from the ancient access to the fort. Photo by Silvia Bertacchi

did the action of the soldiers of Bernia play a decisive role for the coastal defence (Requena Amoraga 1997: 214-226; Pastor Fluixá 1986: 68). Additionally, the outpost left undefended the more important spring in the vicinity, which was one of the primary reasons the fort had been built. To make matters worse, the poor quality of building materials used for the construction, due to the rapidity of the execution, and the weather-beaten location of the fort, besides the strong winds, made frequent maintenance tasks indispensable and had part in the weakness of the defensive building. For example, the roofs were covered with shingles manufactured by Moorish craftsmen and their routine maintenance required nearly 2,400 pieces per year (Salvà Ballester 1960). Finally, the exorbitant costs of maintaining the soldiers of the guard, recorded in the coeval documents (Rojas Claros 2003), was an important factor. 
All these aspects are brought to light in the official report by the viceroy Vespasiano Gonzaga (1531-1591), who visited the outpost in 1575 during a reconnaissance mission along the coast. ${ }^{9}$ In his opinion, the fortress seemed more a hermitage than a deterrent to the enemy. Gonzaga was astonished by the ineptitude of the designer, and in his report for the king he harshly criticized the fort's main shortcomings. First, the location was unsuitable. Second, there were design errors in the proportioning of its parts; for example, the ditch was not deep enough and the embrasures were too large. The viceroy did not consider the rammed earth strong enough to face cannon fire, despite the fact that the external facing of the bastion was made of stone. The two strategic goals were unmet: the spring was not controlled because it was quite far from the outpost, and thus the Moorish people could easily use it during the night; furthermore, the paths were not completely controlled and enemies were able to reach the coast. For all these reasons Gonzaga considered the fort unable to resist cannon fire, which would probably raze it in a short time. Therefore, due to the many problems related to the project and its expensive costs for the kingdom, he proposed to demolish it. The control of the spring water and of the territory could be easily solved by the construction of a masonry tower equipped with heavy artillery.

Within a few years, another very negative opinion was given by the Italian engineer Giovan Giacomo Paleari Fratino (1520/30-1586), a great protagonist of the time and a direct professional rival of Antonelli's, who in 1580 was asked by the king about coastal fortifications. The engineer, even though he never visited the stronghold, agreed with the opinion of his colleague that the fort determined unjustified expenses and was useless. ${ }^{10}$

Despite the recommendation to dismantle the outpost, the fort of Bernia was not immediately destroyed. In 1586 it was still used for the defence against criminals and robbers who were hiding in the mountains, as well as for the control of the Moorish people who tried to escape by sea. By the early seventeenth century, after the expulsion of the Moorish people started in 1609, the fort no longer had any military importance, and in July 1612 the Council of Aragón proposed to the king the dismantling of the garrison. ${ }^{11}$

The last argument in favour of maintaining the outpost was made by Joan Bautista de Urteaga, who had been captain of Bernia since $1606 .{ }^{12}$ Joan begged for the cancellation of the decision, as he considered that fort still essential for the protection of the area. He was convinced that sooner or later the Moorish exiles would come back together with a powerful Turkish army to take revenge for the expulsion from Spain. However, despite Urteaga's plea and after only 50 years of service, the Fort of Bernia was demolished. ${ }^{13}$ In order to prevent the use of the

\footnotetext{
9 The original document in: AGS, GA, leg. 79, fol. 107. A copy exists in the Biblioteca Histórica de la Universitat de València, Spain, Ms. 5, 1575.

10 AGS, GA, leg. 102, 1580; see (Pastor Fluixá 1986: 67).

11 ACA, CA, leg. 555, doc. 5/2 (1612).

12 ACA, CA, leg. 555, doc. 5/6 (probably mid-1612). See also the illustrative drawing of the castle of Bernia by Joan de Urteaga: ACA, CA, leg. 555, doc. 5/16 (1611-12).

13 The order of dismantling dates back to 17 of June 1612 (Requena Amoraga 1997: 225), but according to Francisco Martínez y Martínez (1946: 111) the fort was destroyed in December 1613.
} 


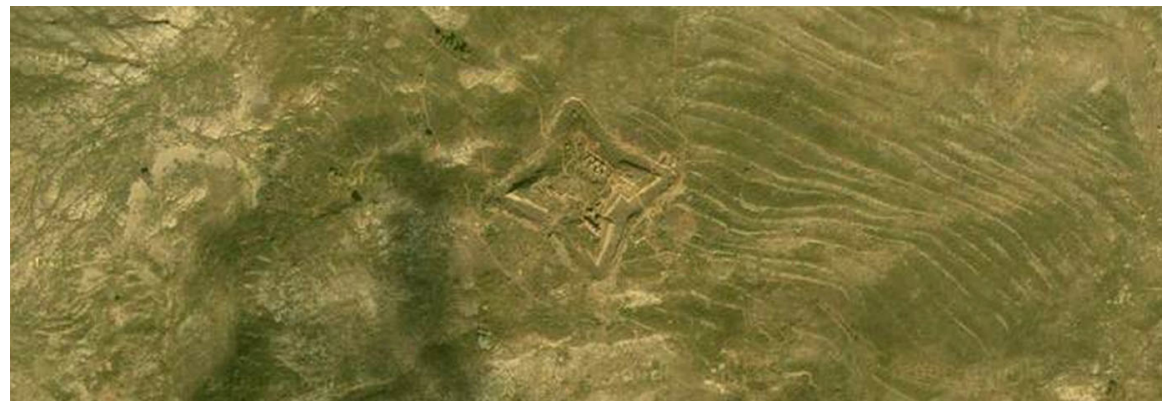

Fig. 9 The plan of the destroyed fort is clearly visible, despite the passing of time. Satellite image by Google Earth 2012

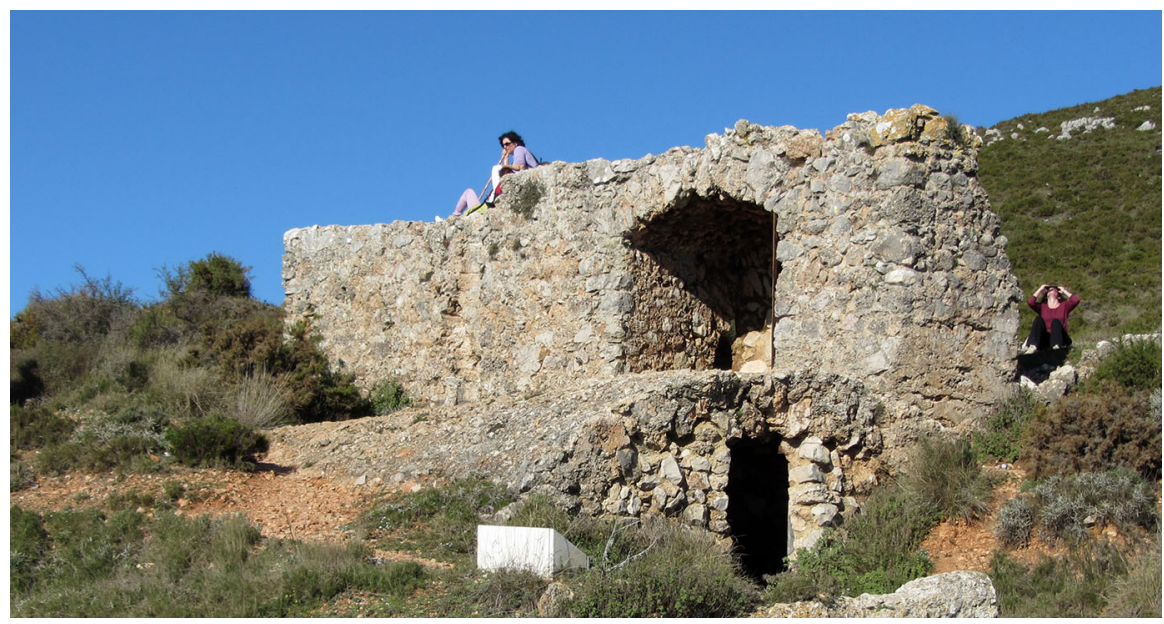

Fig. 10 The so-called "church" was located in a different place in the past. Now there is an altar for visitors in the northern part of the building and it is possible to access a lower interior covered by a vault. Photo by Silvia Bertacchi

outpost by the criminals hidden in the area, the council decided to raze the building, sparing only the foundations, which are still visible today (Fig. 9). In order to avoid desecration, a licence for the demolition of the chapel was issued too (Fig. 10). ${ }^{14}$ After destroying the church, its stones were hidden in a remote location or in a stream, the wooden structures were burnt, the precious vessels moved to the church of Bolulla, and the corpses buried in the church of Callosa. The sacred objects were given to the church of Vergel in Denia, which was very poor. ${ }^{15}$ On 3 April 1613 the work of dismantling the fort of Bernia was complete (Fig. 11). ${ }^{16}$

\footnotetext{
14 Archivo Curia Eclesiastica Valencia, ACEV, Diversorum, 3, fol. 29, 1613; see (Pastor Fluixá 1986: 337-338).

15 Archivo del Reino de Valencia, ARV, Real, Diversorum, leg. 381, fol. 231 r-v, 1613.

16 Archivo del Reino de Valencia, ARV, Mestre Racional, leg. 40, fol. 233, 1613.
} 


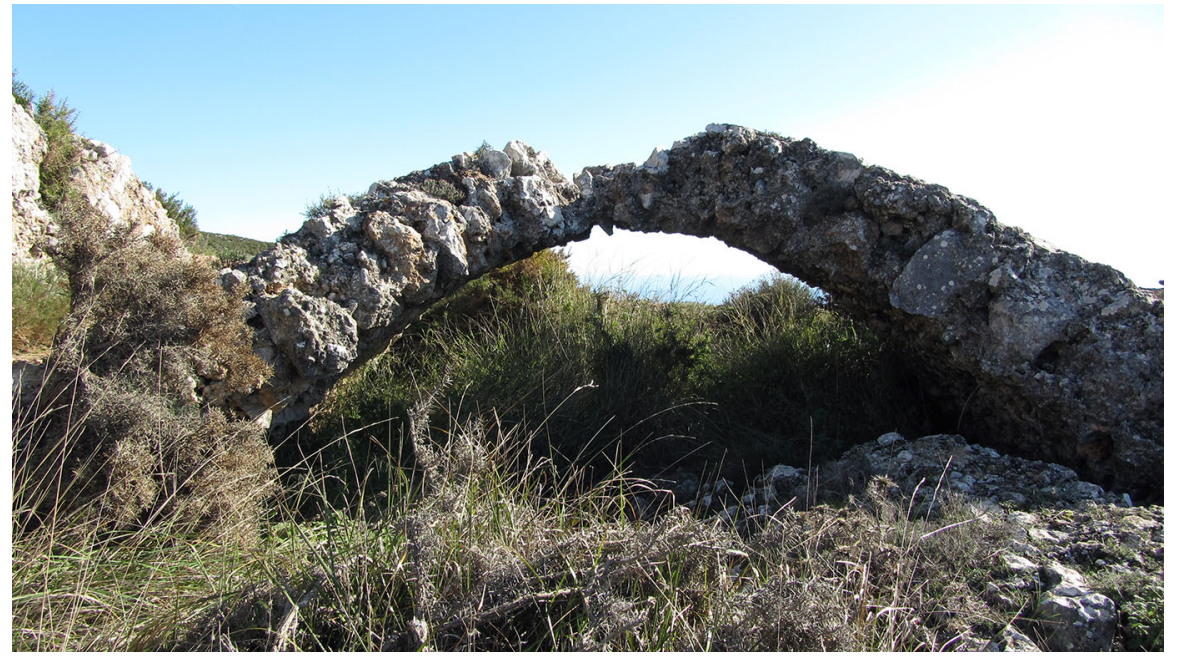

Fig. 11 One of the collapsed vaults of the access level. The ruins show clearly the building technique used for structural elements, which of course could not be built with rammed earth. Photo by Silvia Bertacchi

Geometric analysis of the fort

The model for the fort of Bernia, recommended in the project drawings by Antonelli, was typical of modern fortification: a four-sided symmetrical plan with bulwarks, quite impressive in size, typical of the Italian tradition but built with the traditional Spanish building techniques of rammed earth (tapial). Antonelli probably based his design on his theoretical knowledge more than actually thinking on a feasible defensive building, which was clearly out of place on a mountain slope.

As regards the possible defensive models preferred by technicians or circulating in the coeval treatises, the quadrilateral had been often adopted in the very first period of modern fortifications, and only for small outposts. ${ }^{17}$ The most recent dated at almost ten years before and it had been designed by another Italian engineer, Giovanni Battista Calvi, in the island of Minorca: the castle of San Felipe in Mahón, which was founded near the mouth of a river in 1555 (Moreno García 2009: 2013). Another interesting instance was the Castle of San Leonardo de Yagüe in Soria, part of the inland community of Castilla y León, built in 1563 for Captain Juan Manrique de Lara, Antonelli's patron since his arrival in Spain. ${ }^{18}$ In the overseas territories this typology was present, as confirmed by the construction of the Fuerza Vieja de la Habana, which was symmetrical and characterized by four corner bastions. However, in the New World the outposts

\footnotetext{
17 The Valencian captain Pedro Luis Escrivá had built in 1534 a four-side stronghold in L'Aquila to put down the inhabitants, and in Italy there are a few other examples (Cámara Muñoz 1994: 687).

18 This castle, now in state of ruin, is considered one of the first outposts of the border system to use the model of defensive architecture, a cross-fertilisation between fortification and Renaissance palace design. It cannot be excluded that the captain took advice for his residence from Antonelli, who had just finished the fort in Bernia (Cobos Guerra 2011: 83, 96).
} 
were built on a flat and regular terrain that allowed the perfect symmetry of the plan and created no problems for construction.

The main problem in choosing a quadrilateral-shaped plan was the "sharpness" of the bastions due to the small angle between the two faces, which made them weaker. Antonelli highlighted this problem in the pages of his treatise, suggesting the design of obtuse bulwarks; in light of this, his project in Bernia seems contradictory. ${ }^{19}$ Further, the fort had been built in a disadvantageous area below the summit of the to the mountain; in contrast, in his book on modern fortification the engineer recommended choosing the highest place, far from spurs from which the enemy could shoot with cannons. ${ }^{20}$

The design for the Fort of Bernia is recorded in two original documents that are today preserved in the Archivo General de Simancas (AGS), Spain. Both drawings were found among the documents relating to the fortification of the eastern coast: they are undated and, although not signed, they are attributed to Giovanni Battista Antonelli. ${ }^{21}$ The two detailed documents, a general perspective view of the fortress (Fig. 12) and the plan (Fig. 13), are very interesting because their analysis provides information about metric and proportional aspects of the project, and sheds light on the tools used by the technicians of that period: drawing and geometry. ${ }^{22}$

From the point of view of representation, the graphic aspects are quite accurate, there are no erasures or abrasions, and the state of preservation of the documents is good.

The two drawings are outlined with brown ink and shaded in the sections of the walls; there are some textual annotations for explanation. The representation is clear and firm, proving that the drawing was completed by square rulers to draw precisely parallel lines and right angles, and that the compass was used to trace circular elements. The plan is orientated northward by an arrow-shaped object.

The documents are not dimensioned but are proportioned and complete with a metric scale in local feet. Thanks to this, we could study the different dimensions of

\footnotetext{
${ }_{19}$ Baluardo in particolar: "Li baluardi, come si è detto, si faranno su gli angoli della forma della Città, et havranno da essere sempre ottusi, et non acuti, cioè che la punta denanzi sia di angolo ottuso et non acuto" (Antonelli 1560: $12 \mathrm{r}-\mathrm{v}$ ).

${ }^{20}$ Fortezza de' siti: "Li siti in monte sarano forti, quei che sarano nella cima di qualche monte che da ogni banda habbia le ripe precipitose, o da alcuna parte, et dove non sia monte superiore, né uguale quivi vicino. In somma, tutti li siti in monte de salite difficili sono forti quando non siano offesi da altri monti, et tanto più sono forti quanto se 'l monte sarà di natura difficile a minar, perché quella è la maggior offesa de simili siti (...) il sito più alto intorno al quale non siino poggi o altre eminenze che lo dominino, et che di qui discopra tutto il sito all'intorno a tiro de cannone, che non vi resti cossa alcuna dove ella in questo spatio non offenda tirando" (Antonelli 1560: $8 \mathrm{r}$ ).

${ }^{21}$ The two drawings are preserved in the folder AGS, n. 329-I, fol. 13, 1563: Discurso sobre la fortificación y defensa del Reino de Valencia del Maestre Racional y del ingeniero Juan Bautista Antonelly, Valencia, 30 de marzo de 1563.

${ }^{22}$ The documents are mutually related. However there are some inconsistencies in the drawing between the plan and the perspective, because the section shows all together elements that belong to different levels.
} 


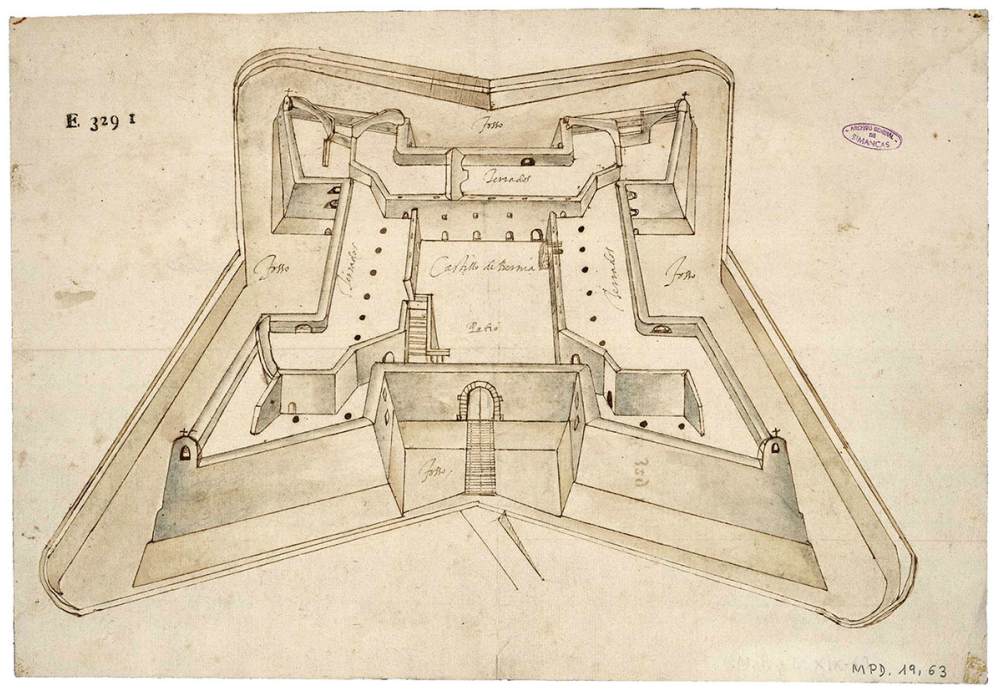

Fig. 12 Perspective view of the fort attributed to Antonelli. España. Ministerio de Educación, Cultura y Deporte. Archivo General de Simancas, MPD, 19, 063, [1563]: Perspectiva de la Fortaleza de Bernia, reproduced by permission

the project and it was possible to make a hypothesis about the design genesis and prove the dimensional aspect of the military outpost. ${ }^{23}$

To the drawings it was attributed by the Spanish archive the date of 1563 since they were preserved with written documents of that year, even though we can assume that they already existed in the previous year. In fact, in the report by Antonelli (1563) there was no reference to the necessity to build a new fortress in Bernia, and perhaps this had already been completed. ${ }^{24}$

The perspective of the fort is fairly accurate and without further modifications, except for the addition of the external stair. The drawing is a bird's eye view, looking toward to the front entrance. This representation system was used by the engineer to show a simple description of space in three dimensions and facilitate a proper understanding of the object by the king, who commissioned the project.

\footnotetext{
23 The problem was the transformation of the old metric unit from Spanish foot to metre, in the purpose of comparing the ideal model to the real construction and point out their possible differences. The experts of the Archivo General de Simancas approved the representation scale in the foot of Castille (pies in Spanish), equal to $27.89 \mathrm{~cm}$, and thus the drawing would be in the scale of 1:214.5. But the measurement of the architectural elements of the whole complex highlights that with this scale doors and stairs would be too small, even considering the obvious reduction of the support shrivelled up with the passage of time. Maybe the Catalan or Aragon foot, slightly larger and equal to $30.3 \mathrm{~cm}$, could have been adopted in the area, leading to a scale of 1:233. In any case, when the Aragon foot is used, the superimposition of the vaults of the quarters and even the underground tunnel coincides with the upper level of the access.

24 "Por tanto se havran de hazer en este reyno dos casas de muniçiones en donde aya toda la artilleria, y muniçiones, y armas q(ue) dara por memoria, de las quales se proveera de presto la gente q(ue) ha de socorrer. La una destas casas se hara en la misma çiudad de Valençia, de la qual se sacara la artilleria para socorrer desde la raya de catalanunia hasta Calpe. La otra por el mal passo de la sierra de Bernia se hara en Origuela para socorrer desde Altea hasta la raya del reyno de Murçia” (Antonelli 1563: 5 v-6 r).
} 


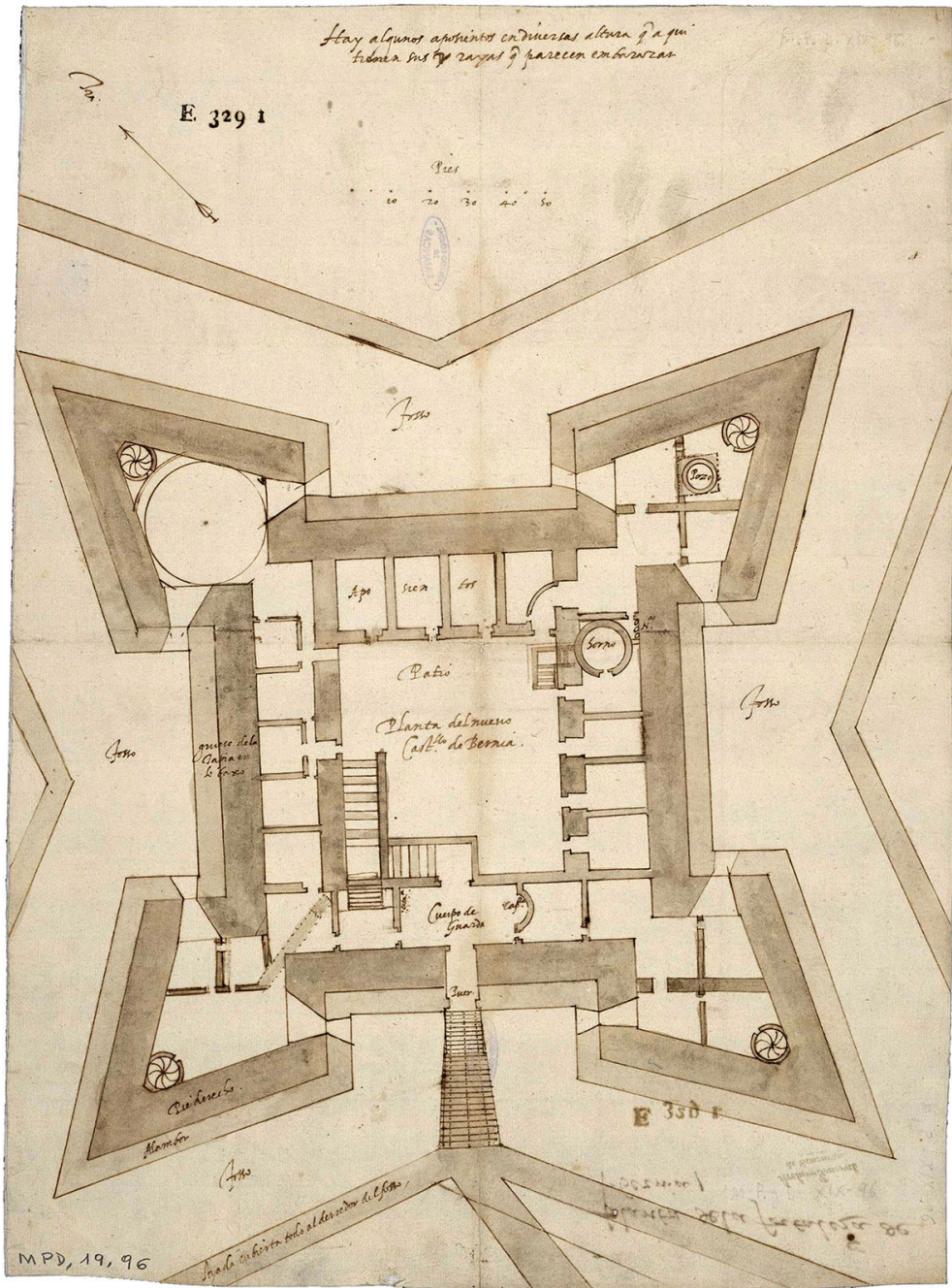

Fig. 13 The plan of Bernia by Antonelli. España. Ministerio de Educación, Cultura y Deporte. Archivo General de Simancas, MPD, 19, 096, [1563]: Planta del nuevo castillo de Bernia, reproduced by permission

The general perspective gives an impression of being slightly deformed, maybe to permit a better understanding of the interior space, and so some elements of the fort are subject to strong visual aberrations. By way of example we note that the upper platform is shown simultaneously almost vertical and in plan. However, the lack of construction lines of the drawing, due to the fact that this is a probably copy from a draft, does not make it possible to determine the method used by Antonelli to put an object into perspective according to the geometrical rules. 


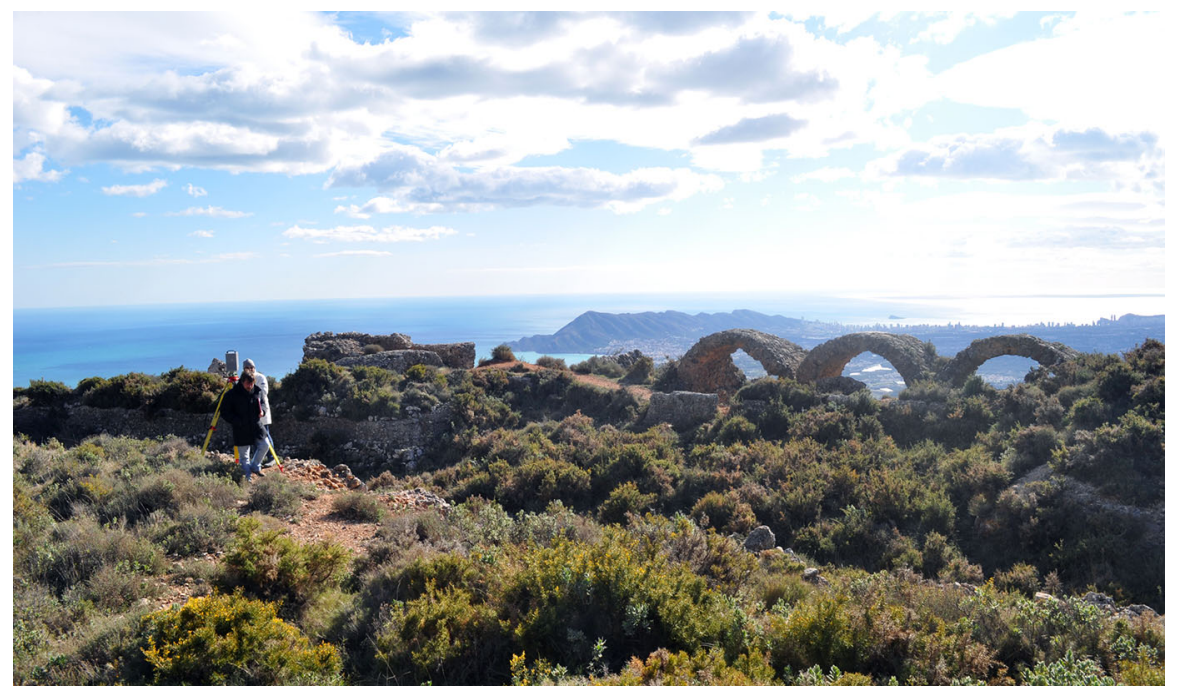

Fig. 14 The survey campaign in February 2012. Photo by Sandro Parrinello

The plan (Fig. 13) shows the ground floor of the fort, at the level of the access to the building. ${ }^{25}$ The symmetrical quadrangle of the defensive system is completed with four corner bulwarks, whose shape is derived from the proportion between the length of the curtain and of the side, on the fire line of the artillery. The inner spaces are organized around a four-sided patio, which served as the parade ground and a central square for accessing all the service areas, such as the room with oven and the quarters for soldiers, each approximately 20 square meters in area. There was also a well in one of the bulwark, noted in Spanish on the document. The connection between the different levels, the basement and the high level of the upper uncovered square, was possible thanks to external stairs or ramps as well as a spiral staircase inserted in the extremities of each of the ramparts. The drawing also shows the projection in plan of some elements of the upper floor, in order to specify the spatial references for the construction of the top wall and to control the correct positioning in the design phase. The thickness of the wall changes depending on the function of the vertical element: thick if structural or defensive, and thin if a dividing wall. In this particular case there is also some information about the building materials and the construction technique of rammed earth and the wall thinner towards the upper level, as can be seen from the perspective drawing. Surrounding the building there was a ditch, not very large and widening towards the end of the bulwarks, and a covered road all around the fortress to protect it from the enemy. The entrance was placed at a higher level from the ground for security reasons, and protected by a double wooden bridge.

Even a general comparison between the original plan by Antonelli and a satellite picture from the web shows the similarity of the proportions between the design shown in the manuscript and the existing remains of the fort, surprisingly clear even

25 The actual dimensions of the manuscript are $43 \times 32 \mathrm{~cm}$. 


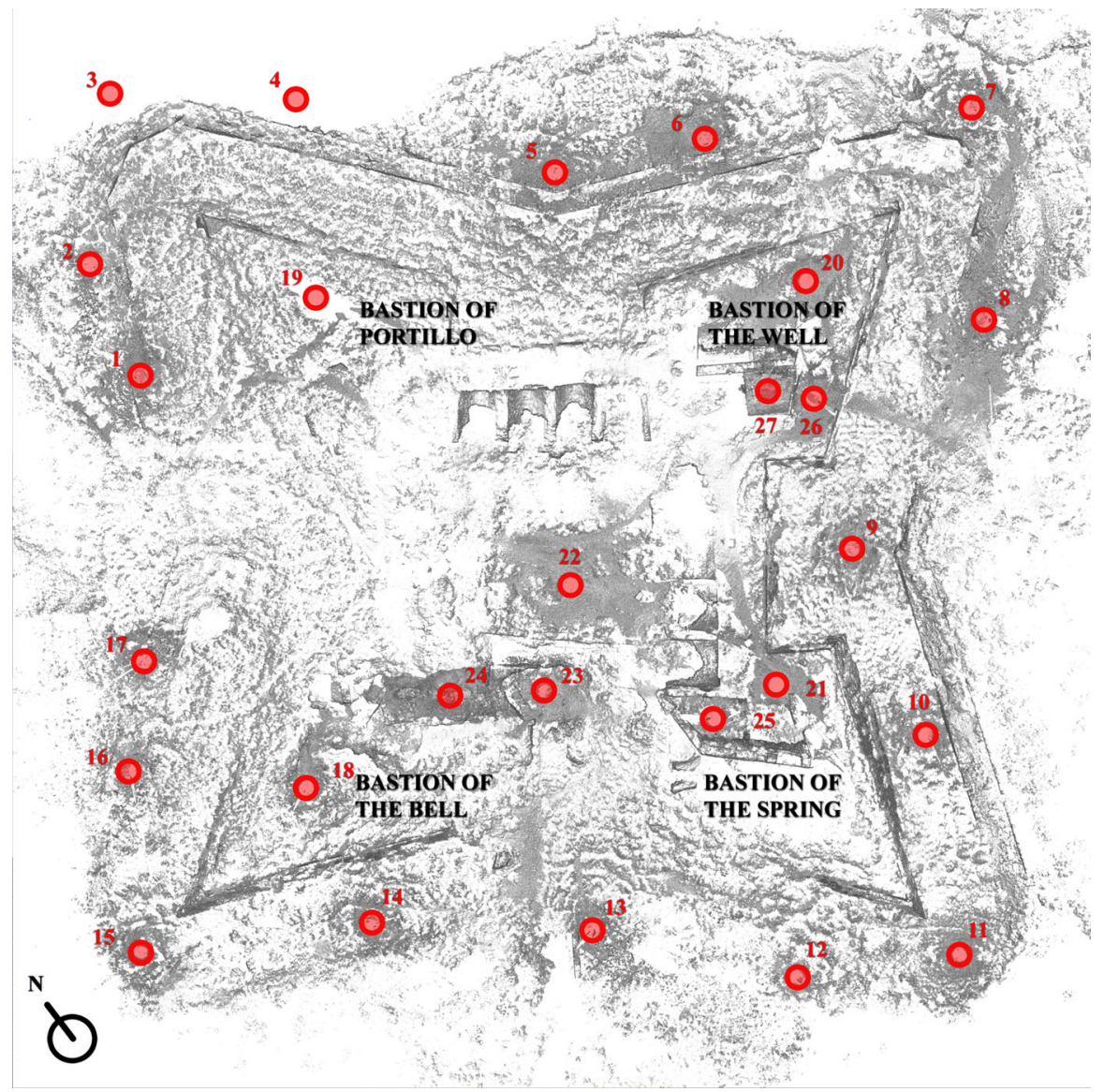

Fig. 15 The 27 scan stations necessary to have a complete view of the fort and the ortho-image of the plan. One of the problems of the survey, besides the state of ruin of the building, was the plentiful vegetation present in the area that covered the remains almost completely

after the almost four centuries that have passed since its destruction. A more indepth verification was carried out by means of the morphometric information gathered through a 3D laser scanner survey (Fig. 14) and high-resolution orthoimages generated from the point cloud (of the plan, fronts and cross-sections, Fig. 15), proving the similarity of the model proposed by Antonelli to and the actual construction. $^{26}$

From that comparison we noticed that the construction is almost identical to what is indicated in the drawing, except for a slight rotation of the axis line of the western bastion on the left side by a few degrees (Fig. 16). This analysis also made it possible to specify the function of elements that no longer exist or are partially

\footnotetext{
26 The laser scanner survey campaign of the ruins of the fort of Bernia (February 2012) was carried on by DigitArca (Ing. L. Chiechi, supervisor Arch. S. Parrinello, collaborator D. Zarrilli) in collaboration with the University of Valencia (Prof. P. R. Navarro).
} 


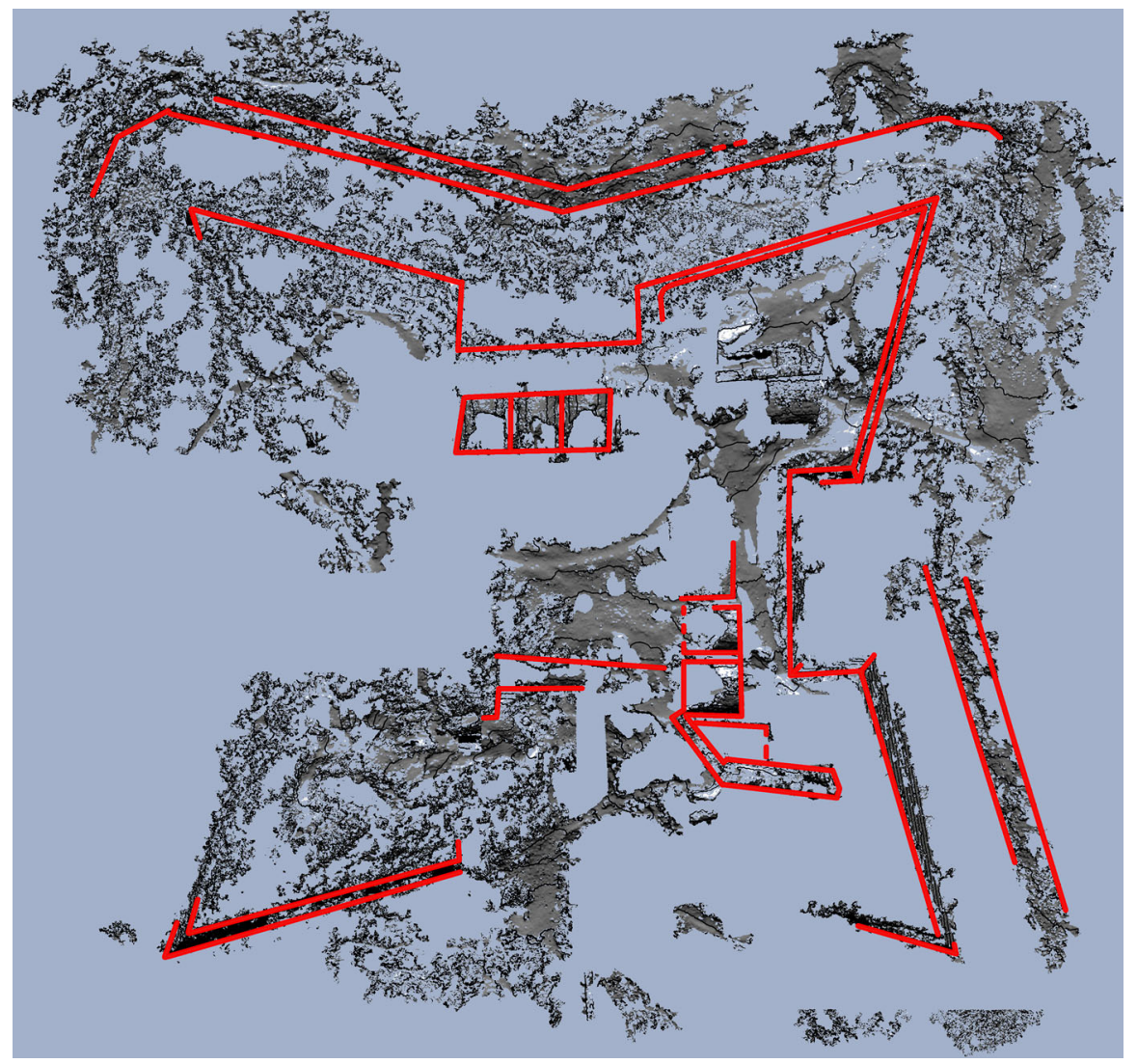

Fig. 16 Mesh model from the 3D survey: in red the existing lines. Image by Silvia Bertacchi

destroyed. For example, the almost completely collapsed walls that were once embrasures can be easily seen when the ruins are compared to the design, as can the remains of the southern bulwark, explained as a later tower instead of the structural wall of the ramp (Fig. 17).

Regarding the matter of dimensions, it was possible to reconstruct the design of the whole complex step by step by taking advantage of CAD tools, processing the morphometric information through geometry and looking for the original design idea by Antonelli.

In the second section of Antonelli's treatise (1560: $12 \mathrm{v}$ ), a short paragraph explained this general rule for the design of a bulwark: to design a bastion, the engineer was to take a distance between 120 and 130 meters from each corner of the plan polygon; then, with a perpendicular line, he was to draw the flank from the curtain with a certain measure explained by the engineer in a table (it depended on the kind of cannons and on the range of their fight). The face of a bastion was defined by a straight line starting from the internal corner of a flank and moving towards the terminal point of the opposite flank. The end of the bulwark was 

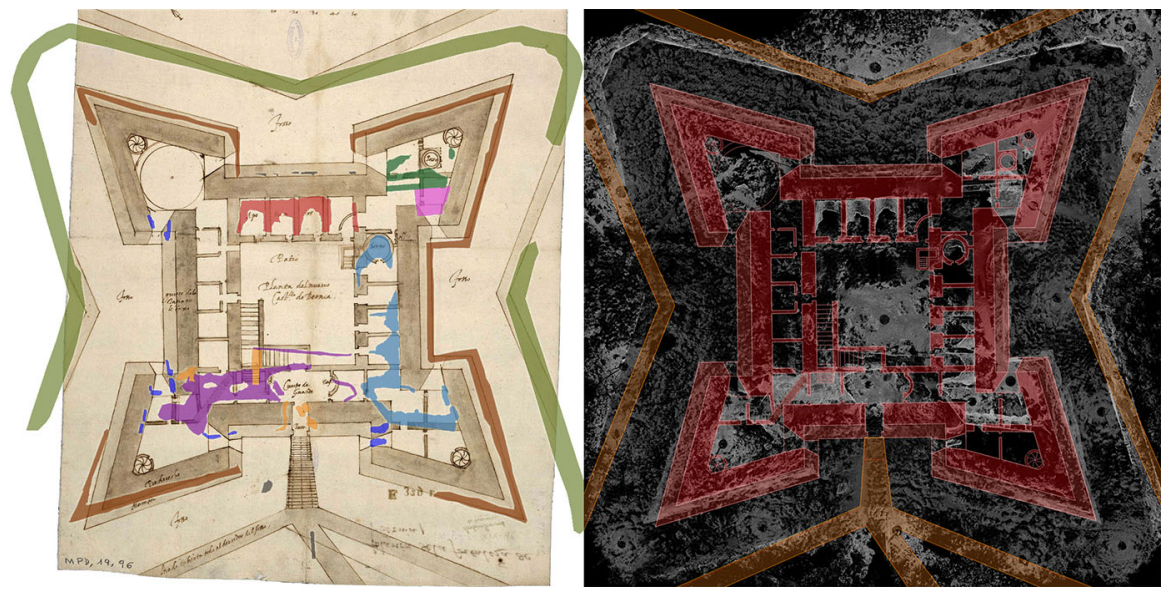

Fig. 17 (a, left) The very interesting comparison between the original project by Antonelli (as per the document shown in Fig. 13) and the remains of the building from the 3D survey (in colour): the architectural elements correspond quite perfectly to the original drawing. In brown colour faces, flanks and curtains of the bulwark; in red vaults of the soldiers quarter; in green the chapel; in blue the embraces; in violet the underground corridor towards the cannons; in light blue vault of the ground floor and ramp; in orange access to the fort; in rose underground vaulted interior; in light green the external walkway. (b, right) Superimposition of the CAD drawing of Antonelli's project on the ortho-image of the plan from the point cloud. The precision of the real fort is impressive, especially considering the appreciable slope on which the fort is placed (in red the project by the engineer, in orange the defensive walkway around the fort)

determined by the intersection of two intersecting lines originating from opposite sides. $^{27}$

In the case of the fort of Bernia, the metric analysis of the original project allowed us to confirm without a doubt that Antonelli followed the method proposed in his treatise (Fig. 18). It is evident that the engineer designed the fort with a preference for the use of whole numbers; for example, the thickness of the wall is 10 feet, that of the dividing walls is 6 feet, and that of the buttresses is 3 feet. The plan develops from a square of 100 feet for the inner side and 120 outside. The whole lower area, including the projection of the slope in lighter colour, had the total width of 134 feet. The quadrilateral spaces were to be perfect squares, according to the indication in the document, which has only a small error in the measurements. Each side was to be 25 feet long, starting from the inner corner of the square and

\footnotetext{
27 "Per far detto baluardo, si pigliarà da ogni parte dell'angolo onde egli si ponerà, da cento venti in cento trenta piedi per la piazza dell'artiglierie alte et basse, et loro parapetti et piazze di esso baluardo, et nel fine di questo numero si pigliarà il fianco ad angolo retto sopra sopra la cortina grande della quantità che si dirà nella tavola, dalla estremità della qual misura si farà l'orechione verso l'altro baluardo della lunghezza che ha da essere, et pigliata la larghezza sua con linea parallela al fianco, dal fine della sua larghezza, et dal punto dell'altro fianco, che guarda verso questo, si tirerà una linea indeffinita, et facendo il medesimo dall'altra parte dell'angolo, le due linee indeffinite s'intersecaranno. La quale intersecatione farà l'angolo o punta, et fronte del baluardo siino alquanto ficcate dalla prima cannonera de quel fianco, onde si piglia la loro diffesa, et però si potrà pigliar il punto alquanto lontano da esso fianco su la cortina longa non causando però il baluardo molto acuto, et volendosi similmente far maggiore o menare il baluardo, si augmentaranno le loro mesure secondo il bisogno" (Antonelli 1560: $12 \mathrm{v})$.
} 


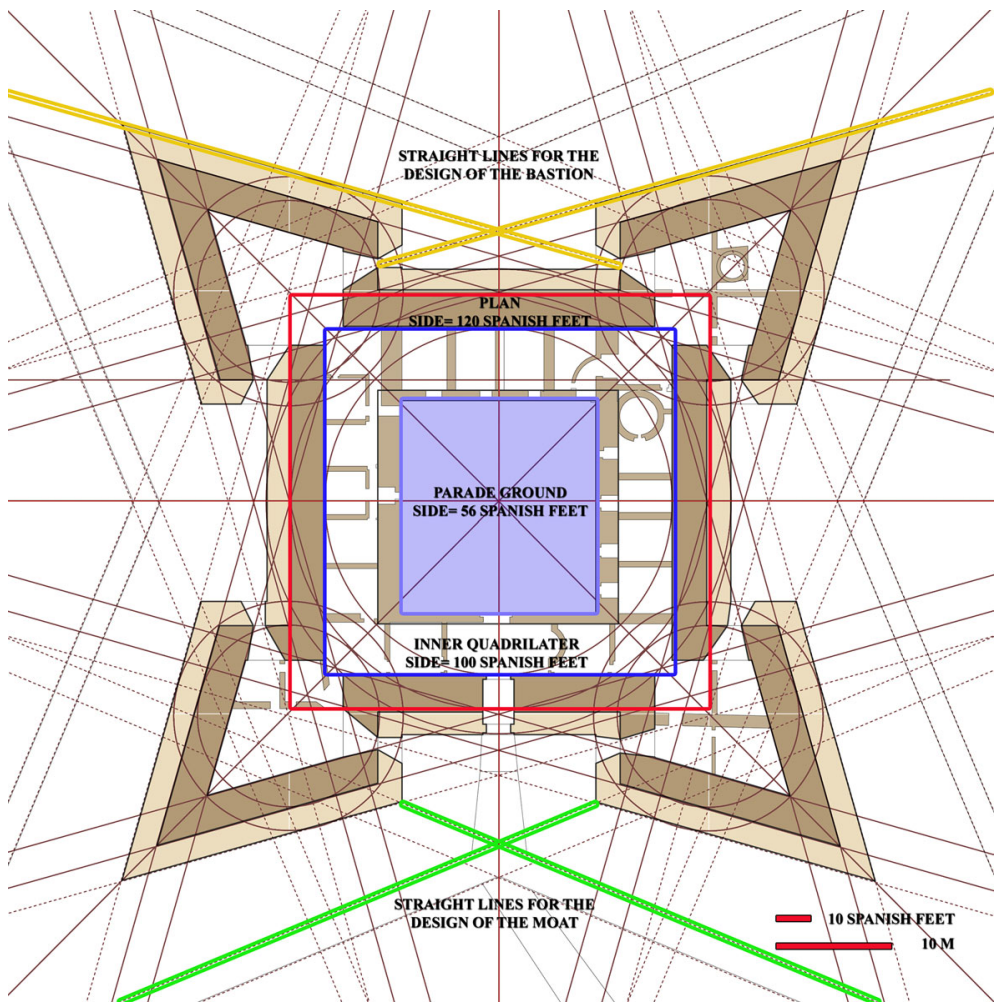

Fig. 18 Geometrical scheme of the fort. Highlighted are the design rules for drawing the bastions and the moat. Image by Silvia Bertacchi
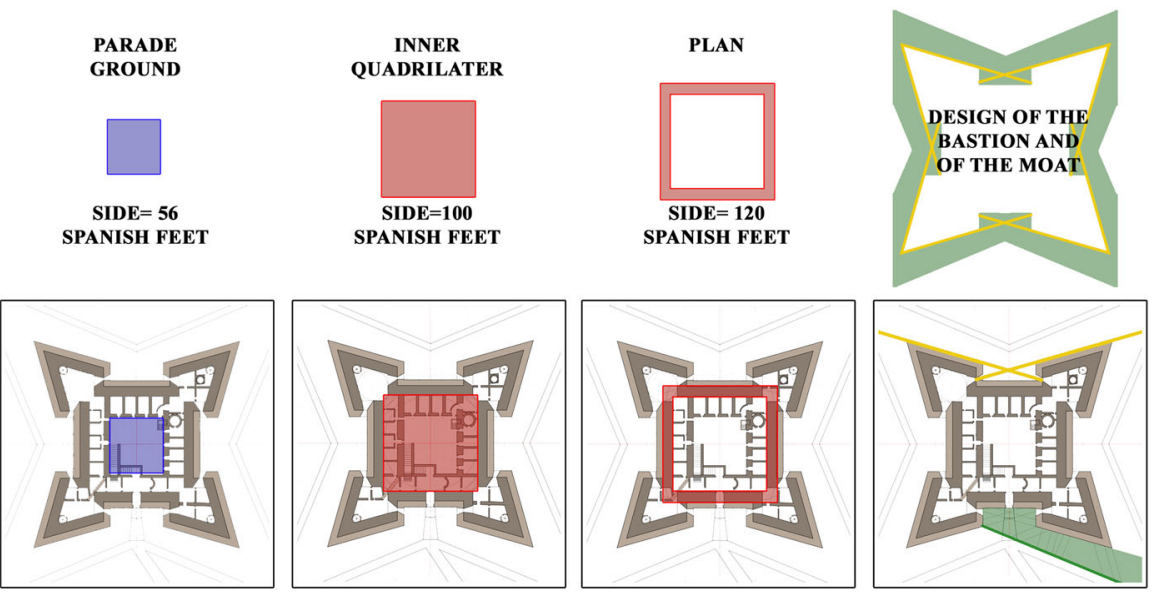

Fig. 19 Steps for the design of a star-shaped fort and pertinent dimensions. Image by Silvia Bertacchi 


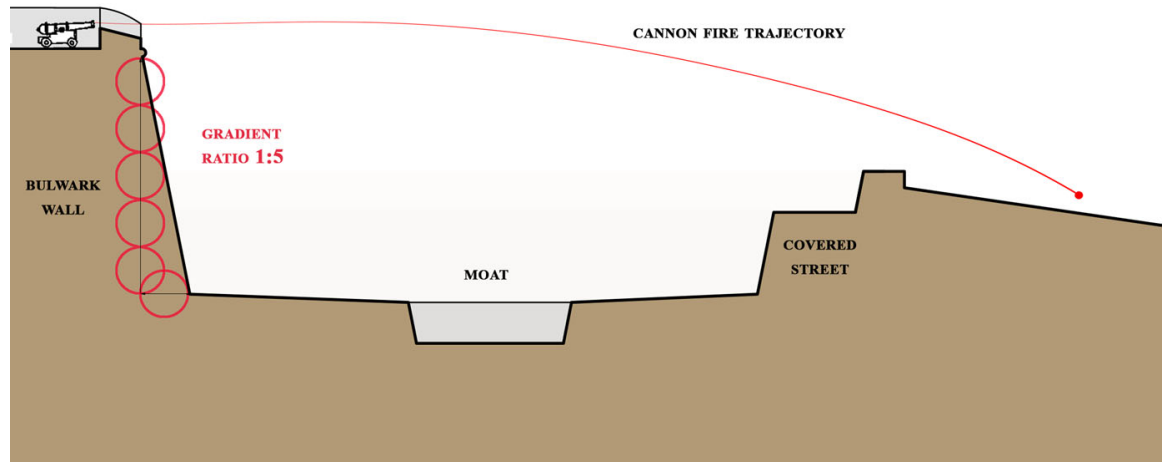

Fig. 20 The theoretical rule proposed by Antonelli in case of stone walls is to decrease the external wall thickness by 1 foot for every 5 feet in height. The scheme shows the ideal proportions for a royal bulwark of a large fortress and the curved line of cannon fire trajectory. The fort of Bernia uses the same decreasing ratio, with a smaller dimension for the moat. Image by Silvia Bertacchi

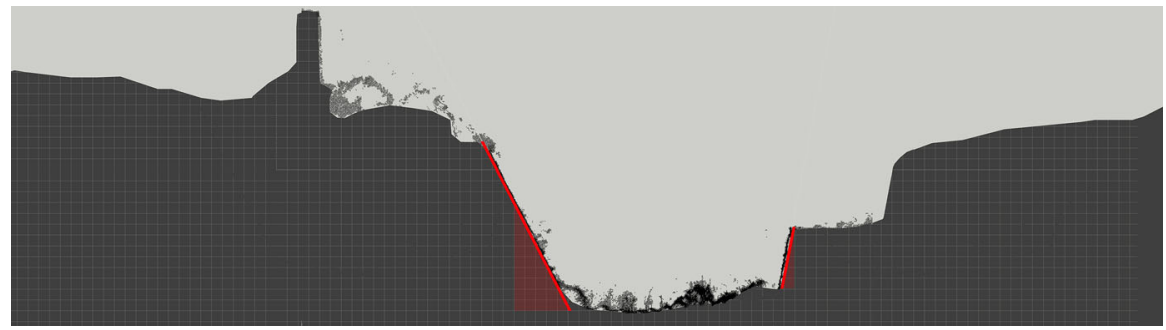

Fig. 21 Actual section gradient of the walls of the fort of Bernia and the external surrounding walkway from the study of the digital survey. Image by Silvia Bertacchi
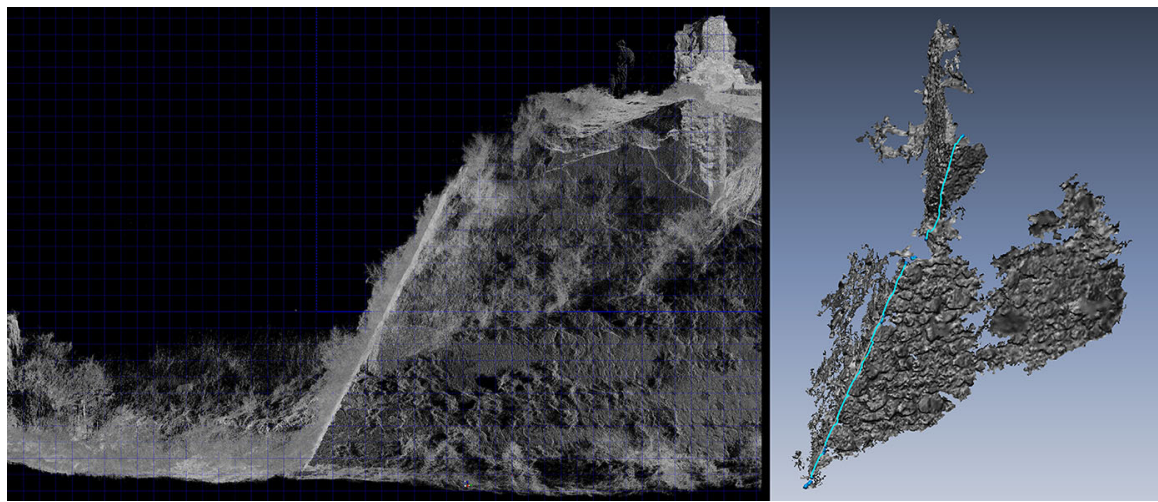

Fig. 22 Elaborations to study the gradient of the bastion end, by the point cloud and by the mesh model. Model by Silvia Bertacchi 
perpendicular to the line of the curtain. The ditch had a maximum width of 30 feet and the external surrounding road was 7 feet (Fig. 19). With regard to heights, there are no indications either written or drawn on the document. However, it was a general rule to reduce the thickness by one foot for every 5 feet of height in the case of stone walls (Fig. 20). In fact, in his treatise (1560-1561: 13 r) Antonelli suggested to consider 5 additional feet in the plan of a building, probably indicated in this case by the lighter colour. In addition, the $3 \mathrm{D}$ survey appears to indicate that the foundation of the ramparts, still existing, had a gradient halved in comparison to the general rule, probably for practical reasons (Figs. 21, 22).

\section{Conclusions}

The Fort of Bernia represents Antonelli's worst experience and his total failure as a military engineer. This was perhaps due to his inexperience, since it was the very first fortification he designed in Spain and the only one actually built, in addition to a too hasty consent to the project on the part of the institutions, possibly due to fear more than to the real danger of an imminent revolt by the Moorish people conniving with Berber pirates. Moreover, because of his too strict adoption of the defensive model in a mountainous site, a model "by the book" that failed miserably as it contradicts two of the most important rules given by Antonelli in his treatise: the analysis of the site morphology, and adaptation of the fortification to the geographical particularities (Bertacchi 2013b). Be that as it may, this fort is a perfect example of geometrical design for a defensive building. Thanks to the study of modern documentation and the fact that the original drawing are still existing, and by means of a comparison between the design and a 3D laser scanner survey of the ruins, an in-depth analysis of the military outpost made it possible to prove that Antonelli used geometry as a tool for the project.

\section{References}

Amoraga, Requena, and Francisco Requena Amoraga. 1997. La defensa de las costas valencianas en la época de los Austrias. Alicante: Instituto de Cultura Juan Gil Albert.

Arciniega García, Luis. 1999. Defensas a la antigua y a la moderna en el Reino de Valencia durante el siglo XVI. Espacio, Tiempo y Forma 12, VII: 61-94.

Antonelli, Giovanni Battista. 1560. Epitomi delle fortificazioni moderne di Giovambatta Antonelli, manuscript not published, reprinted in its original form by Sartor 2004-a.

Antonelli, Giovanni Battista. 1563. Discurso sobre la fortificación y defensa del Reyno de Valencia del maestre racional de aquel Reyno, y de Juan Bautista Antoneli, manuscript not published, in Archivo General de Simancas (Spain), AGS, Estado, I: fol. 13.

Bertacchi, Silvia. 2013a. Modelli compositivi per la difesa "alla moderna". L'esperienza di Giovanni Battista Antonelli. Ph.D. thesis, Università di Firenze, Dipartimento di Architettura.

Bertacchi, Silvia. 2013b. L'arte fortificatoria dell'ingegnere italiano Giovanni Battista Antonelli: un'analisi fra teoria e pratica militare tardo cinquecentesca. In Scuola Nazionale di Dottorato in Scienze della Rappresentazione e del Rilievo-U.I.D. Unione Italiana del Disegno. Linee di ricerca nell'area del Disegno. Approfondimenti dalle tesi di dottorato. X Congresso UID Matera 2013 
(Proceedings of the XXXV Convegno Internazionale delle Discipline della Rappresentazione, Matera, 24-26 ottobre 2013), ed. Laura Carlevaris, 113-122. Rome: Aracne Editrice.

Cámara Muñoz, Alicia. 2004. Giovanni Battista Antonelli e la definizione professionale dell'ingegnere nel Rinascimento spagnolo. In Omaggio agli Antonelli. Considerazioni intorno a tre generazioni di architetti militari italiani attivi nel Mediterraneo e in America (Atti del Convegno Internazionale di Studi, Gatteo 3-5 ottobre 2003), ed. Mario Sartor, 163-218. Udine: Forum.

Cámara Muñoz, Alicia. 2005. Los guardianes del mar: fortificaciones, torres y atalayas en la costa valenciana (siglo XVI). Pp. 201-220 in Jornadas del Bicentenario de Torrevieja, 1803-2003, Vera Rebollo and Jose Fernando, eds. Torregrosa: Instituto Municipal de Cultura Joaquín Chapaprieta.

Cataneo, Pietro. 1554. I primi quattro libri dell'architettura di Pietro Cataneo senese: nel primo de' quali si dimostrano le buone qualità de' siti, per l'edificationi delle città \& castella, sotto diversi disegni: nel secondo, quanto si aspetta alla materia per la fabrica: nel terzo si veggono varie maniere di tempii, \& di che forma si convenga fare il principale delle città: \& delle loro piante, come ancora dalle piante delle città e castella, ne sono tirati gli alzati per ordine di Prospettiva: nel quarto si dimostrano per diverse piante l'ordine di più palazzi \& casamenti, venendo dal palazzo regale e signorile, come di honorato gentilhuomo, sino alle case di persone private. Venezia.

Cebrián Gimeno, Rafael. 1997. Montañas valencianas VI: Sierra de Aitana y Puig Campana-Sierras de Serrella, Xortá, Bèrnia y del Ferrer-El Peñon de Ifac, 256-276. Centre Excursionista de València: Papers de muntanya XIII. Valencia.

Escolano, Gaspar. 1611. Segunda parte de la Decada primera de la historia de la ciudad i Reyno de Valencia. Valencia: Pedro Patricio Mei.

Gasparini, Graziano. 2007. Los Antonelli. Arquitectos militares italianos al servicio de la Corona española en España, Africa y América (1559-1649). Venezuela.

Llaguno y Amirola, Eugenio; Céan Bermúdez, Juan Augustin. 1829. Noticias de los arquitectos y arquitectura de España desde su restauración. Madrid.

León Vidal, Pablo. 2009. Defensa costanera i control dels moriscos als segles XVI-XVII: el Fort de la Serra de Bèrnia. Alberri: Quaderns d'investigacio del centre d'estudis contestants 19:77-156.

Maggiorotti, Leone Andrea. 1939. L'opera del genio italiano all'estero. La libreria dello Stato: Gli architetti militari III. Rome.

Martínez, Garcia. 1980. Bandolers, Corsaris i Moriscos. Valencia: Eliseu Climent.

Martínez y Martínez, Francisco. 1946. El "fort" o castillo de Bernia. Saitabi 20-21: 110-116.

Moreno García, Rafael, and Benayas, David. 2009. El fuerte abaluartado de la Sierra de Bernia, la controvertida historia de una fortaleza y su función en la lucha contra los moriscos y corsarios. Castillos de España. 156-159: 207-214.

Parrinello, Sandro. 2012. Documentation of the Antonellis' Fortresses. In Between East and West: Transposition of cultural systems and military technology of fortified landscapes (Congress Proceedings, Poppi (AR), 7-13 May 2012), ed. Sandro Parrinello, Stefano Bertocci and Giovanni Pancani, 253-269. Florence: Edifir Edizioni.

Parrinello, Sandro; Bertacchi, Silvia. 2012. Giovanni Battista Antonelli: theory, model and reality. In Between East and West: Transposition of cultural systems and military technology of fortified landscapes (Congress Proceedings, Poppi (AR), 7-13 May 2012), ed. Sandro Parrinello, Stefano Bertocci and Giovanni Pancani, 184-187. Florence: Edifir Edizioni.

Parrinello, Sandro; Bertacchi, Silvia. 2013. La città ed il territorio nella strategia difensiva spagnola del XVI secolo: l'esperienza dell'ingegnere militare Giovanni Battista Antonelli. In Città e Territorio. Conoscenza, tutela e valorizzazione dei paesaggi culturali (Congress, Massa Marittima (GR), 9-11 novembre 2012) Collana Confronti 1, ed. Giulia Galeotti and Marco Paperini, 302-303. Livorno: Debatte editore/Centro Studi Città e Territorio.

Pastor Fluixá, Jaume; Campón Gonzalvo, Julia. 1986. Papers de Bèrnia: documents i comentaris històrics sobre el fort de Bèrnia. Callosa d'en Sarrià (Alicante): Ayuntamiento de Callosa d'en Sarrià.

Rojas Claros, Francisco; Ronda Pérez, Joaquín. 2003. Papers del fort de Bèrnia: colleccionats por Adolf Salvà i Ballester, any 1931. Callosa d'En Sarrià (Alicante): Istituto Alicantino de Cultura "Juan GilAlbert".

Salvà i Ballester, Adolf. 1960. La villa de Callosa de Ensarria: monografía histórica documentada. Alicante: Instituto de Estudios Alicantinos.

Sartor, Mario. 2004a. Giovan Battista Antonelli, Epitomi delle fortificationi moderne. Udine: Forum.

Sartor, Mario. 2004b. Omaggio agli Antonelli. Considerazioni intorno a tre generazioni di architetti militari italiani attivi nel Mediterraneo e in America (Atti del Convegno Internazionale di Studi, Gatteo, 3-5 ottobre 2003). Udine: Forum. 
Valor Serra, Jordi. 1950. Subida al fuerte de Bernia, último reducto del Islam español. Revista Valencia Attracción 180, XXV, 2:2-4.

Zanchi, Giovanni Battista. 1554. Del modo di fortificar le citta' trattato di M. Giouambattista de' Zanchi, da Pesaro, al serenissimo et inuittissimo re Massimiliano d'Austria, re di Boemia. Venezia: Plinio Pietrasanta.

Sandro Parrinello is architect and researcher at the Department of Civil Engineering and Architecture at the University of Pavia, Italy, and a European Ph.D. in Science of Surveying and Representation of Architecture and Environment. He is professor of Architectural Drawing and Computer Graphics at the Faculty of Engineering in the "Laurea" degree program of Science in Civil Engineering/Architecture at the University of Pavia and professor of Landscape Representation in the "Laurea" degree program in Landscape Design at the University of Florence. His research aims at representing landscape by means of drawing. Since 2005 he has been carrying out the research and the survey of the fortresses designed by the Antonelli family all around the world, especially in the Caribbean area.

Silvia Bertacchi is an architect with a Ph.D. in the Science of Surveying and Representation of Architecture and Environment at the Department of Architecture, University of Florence. She is an adjunct professor of "Drawing" for the Bachelor Degree in Construction Engineering at the Alma Mater Studiorum, University of Bologna, Campus of Ravenna and visiting assistant professor for the academic year 2013/2014 of "Descriptive Geometry" for the Master Degree in Architecture, University of Ferrara. Her research is mainly focused on descriptive geometry and its application on architecture. She received her Ph.D. with a thesis on Antonelli's compositional models in the field of military architecture, especially in Spain, analysing in depth his treatise and the geometrical tools for the design of defensive buildings. 